\begin{tabular}{|l|l|l||}
\hline \multicolumn{2}{|c|}{ PublisherInfo } \\
\hline \hline PublisherName & $:$ & BioMed Central \\
\hline \hline PublisherLocation & $:$ & London \\
\hline \hline PublisherImprintName & $:$ & BioMed Central \\
\hline \hline
\end{tabular}

\title{
Plague genome
}

\begin{tabular}{||l|l|l||}
\hline \multicolumn{2}{|c||}{ ArticleInfo } \\
\hline \hline ArticleID & $:$ & 4216 \\
\hline \hline ArticleDOI & $:$ & $10.1186 /$ gb-spotlight-20011004-01 \\
\hline \hline ArticleCitationID & $:$ & spotlight-20011004-01 \\
\hline \hline ArticleSequenceNumber & $:$ & 287 \\
\hline \hline ArticleCategory & $:$ & Research news \\
\hline ArticleFirstPage & $:$ & 1 \\
\hline \hline ArticleLastPage & $:$ & 2 \\
\hline \hline & & \\
\hline ArticleHistory & $:$ & RegistrationDate : 2001-10-04 \\
\hline \hline ArticleCopyright & $:$ & OnlineDate $\quad:$ 2001-10-04 \\
\hline \hline ArticleGrants & $:$ & \\
\hline \hline ArticleContext & $:$ & 130592211 Central Ltd2001 \\
\hline \hline
\end{tabular}




\section{Jonathan B Weitzman}

Email: jonathanweitzman@hotmail.com

Yersinia pestis is a Gram-positive bacterium that has wreaked havoc for centuries by causing plague pandemics such as the Black Death. Threats that $Y$. pestis could be used as a biological warfare agent suggest that it will continue to provide a healthcare challenge in the future. In the October 4 Nature, Parkhill et al. from The Sanger Centre report the complete genome sequence of the Y. pestis strain CO92 (Nature 2001, 413:523-527). The killer genome consists of a 4.65 megabase chromosome and three plasmids (of 96.2, 70.3 and $9.6 \mathrm{~kb}$ ). Anomalies in GC composition bias in the Y. pestis genome suggest frequent intragenomic recombination events, and there is ample evidence for lateral transfer and horizontal gene acquisition from other bacteria and insect parasites. Genes whose function has been lost during evolution (leading to pseudogene accumulation) include those for motility, lipopolysaccharide biosynthesis and characteristics of enteropathogenicity. Parkhill et al. suggest that comparative genomic analysis will reveal what determines the evolution of virulent pathogens such as $Y$. pestis.

\section{References}

1. Yersinia pestis - etiologic agent of plague.

2. Nature, [http://www.nature.com]

3. The Sanger Centre, [http://www.sanger.ac.uk]

4. Y. pestis genome, [http://www.sanger.ac.uk/Projects/Y_pestis/] 